\title{
FUNCTIONS THAT CAUSE AFFECTING THE IMPLEMENTATION OF REENGINEERING IN TERMS OF ECONOMIC IMPACT
}

\author{
Slobodan Stefanovic ${ }^{1}$, Radoje Cvejic ${ }^{2}$, Dusko Kostic ${ }^{3}$, Radojko Lojanicic ${ }^{4}$ \\ ${ }^{1}$ Graduate School of Applied Professional Studies, Vranje, Serbia, ${ }^{2}$ Associate Professor, Faculty for strategic and \\ operational management, Belgrade, Serbia, ${ }^{3}$ HighVocational School for Entrepreneurship, Belgrade, Serbia, ${ }^{4}$ Associate \\ Professor, Faculty for strategic and operational management, Belgrade, Serbia.
}

\begin{abstract}
This paper work includes general financial parameters of small and medium enterprises which causal influence on the implementation of reengineering in transition economies through: management processes, Luirao marketing functions, functions of scientific research, the function of management approach in planning production, development and control aspects of business operations with the economic and financial effects. Based on these parameters the financial analysis of major economic indicators of application of reengineering in small and medium enterprises is shown.
\end{abstract}

The design of small and medium enterprises through re-engineering must be comprehensive (systems approach) and that there is an effective methodology which depends on the specific enterprises Aspect of the analysis should focus on the cost of the company.

Key words: Reengineering, small and medium enterprises, financial parameters, business functions, process management.

\section{INTRODUCTION}

Business functions to their proper concept, content and organization of companies providing efficient business ie. achieving given business goals. Small or medium-sized enterprise is a system in which information is collected and processed, make decisions and perform actions which change the state of the enterprise system and is characterized by the following features that causally affect to the implementation of reengineering in terms of general financial parameters $^{1}$ :

1 S. Stefanović, R. Cvejic, D. Kostic, FUnCTIONS THAT CAUSATIVE AFFECTS TO THE IMPLEMENTATION OF REENGINEERING FROM THE ASPECT OF GENERAL FINANCIAL PARAMETERS, Lucrarea trimisă redacției Metalurgia
1. management processes $\left(R_{P R}\right)$,

2. Luirao - marketing functions $\left(R_{M}\right)$,

3. functions of scientific research $\left(R_{N R}\right)$,

4. function management approach in production planning $\left(R_{M d \mid}\right)$,

5. functions of financial planning for the development of enterprises $\left(R_{P}\right)$,

6. functions of planning and control of operations $\left(R_{P K P}\right)$,

7. economic - financial functions $\left(R_{E F F}\right)$,

8. binding function of earnings performance $\left(R_{V Z P}\right)$.

\section{PROCESSES MANAGEMENT $\left(R_{P R}\right)$}

Competitive interaction between sellers and buyers can be a relationship of competitions and negotiation. Competitive ratio meets the requirements of consumers, while the relationship agreement favors one group or sellers with the same or similar strategies to meet the needs of customers.

Strategic behavior of the company, certain of its product line, which participates in the market, it may be adaptive environment, ie. other companies can co-operate with them, and can be a conflict. What behavior will choose the company depends on its location in the middle of his potential.

The company, due to their relationship with the environment, selects routes, methods and pace of its growth and development, ie.

International a fost acceptată spre publicare în numărul din 2013 ., ISSN 1582 - 2214, "METALURGIA INTERNATIONAL" is introduced in THOMSON SCIENTIFIC MASTER JOURNAL LIST, letter M, position 440. vol. 18 SPECIAL ISSUE NO. 8, str. $240-$ 246 (2013). 
development strategy as a set of decisions about what and how to implement in a given time, and how to realize long-term goals. In relation to the coverage of the market covered by specific company, the competitive advantage that the company has, and the financial effect of which is realized will depend on the choice of strategy. A company can choose the strategy of development or conservation development strategy better than the previous development. For which of these two strategies of the company is to decide, depending on whether its growth and development on a production scale (defensive strategy) or flexible manufacturing systems (offensive strategy).

Both can be specified for the entire company and some of its functions. A special place has to take the strategy for winning new production, which has a base for its innovation strategy, ie. a strategy of research and development.

Business functions in a small or medium enterprises make up an important segment of the business enterprise (Figures 1., 2., 3. - business functions $1,2,3$ ).

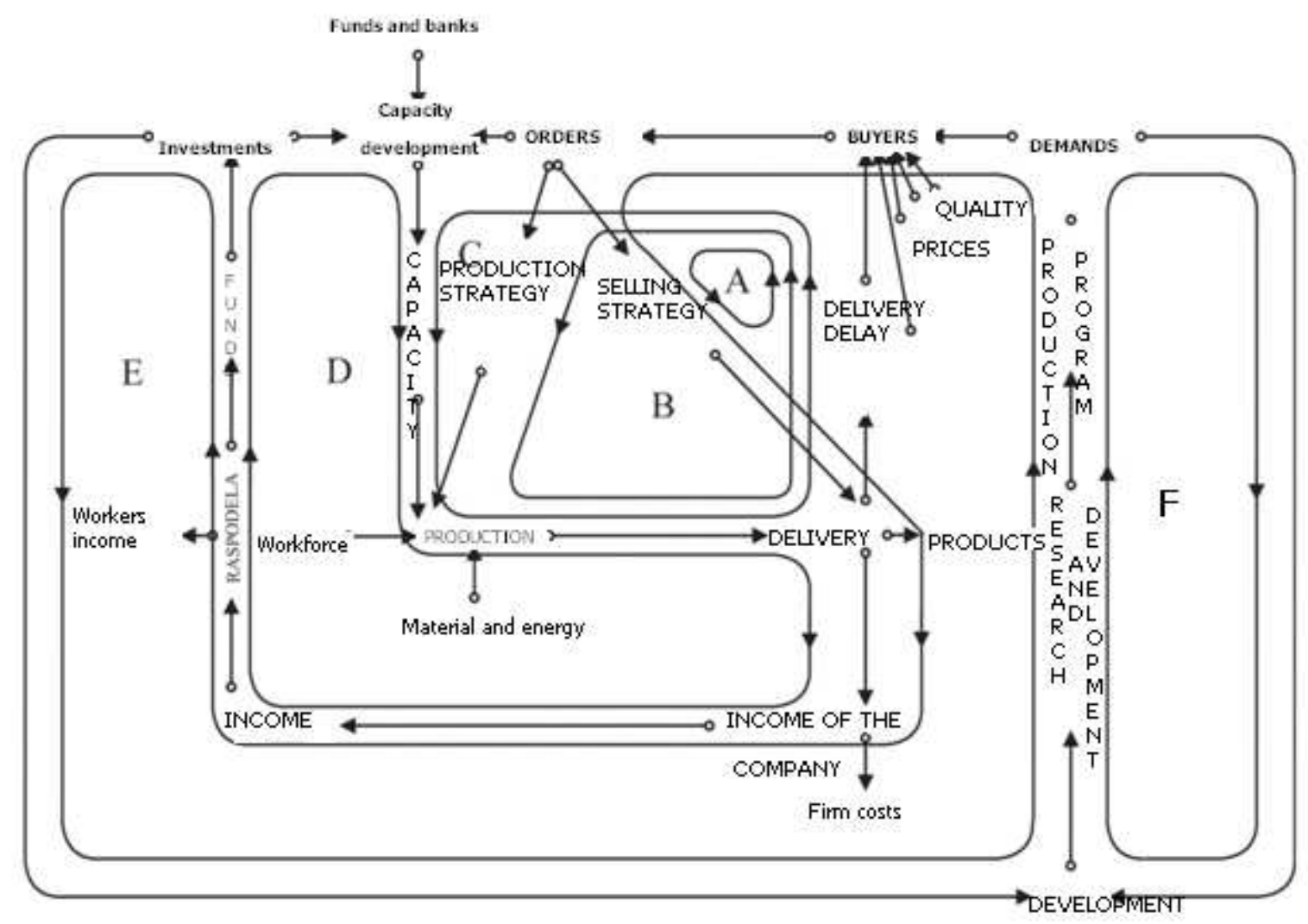

Figure 1. Processes management - Business Functions 1. 


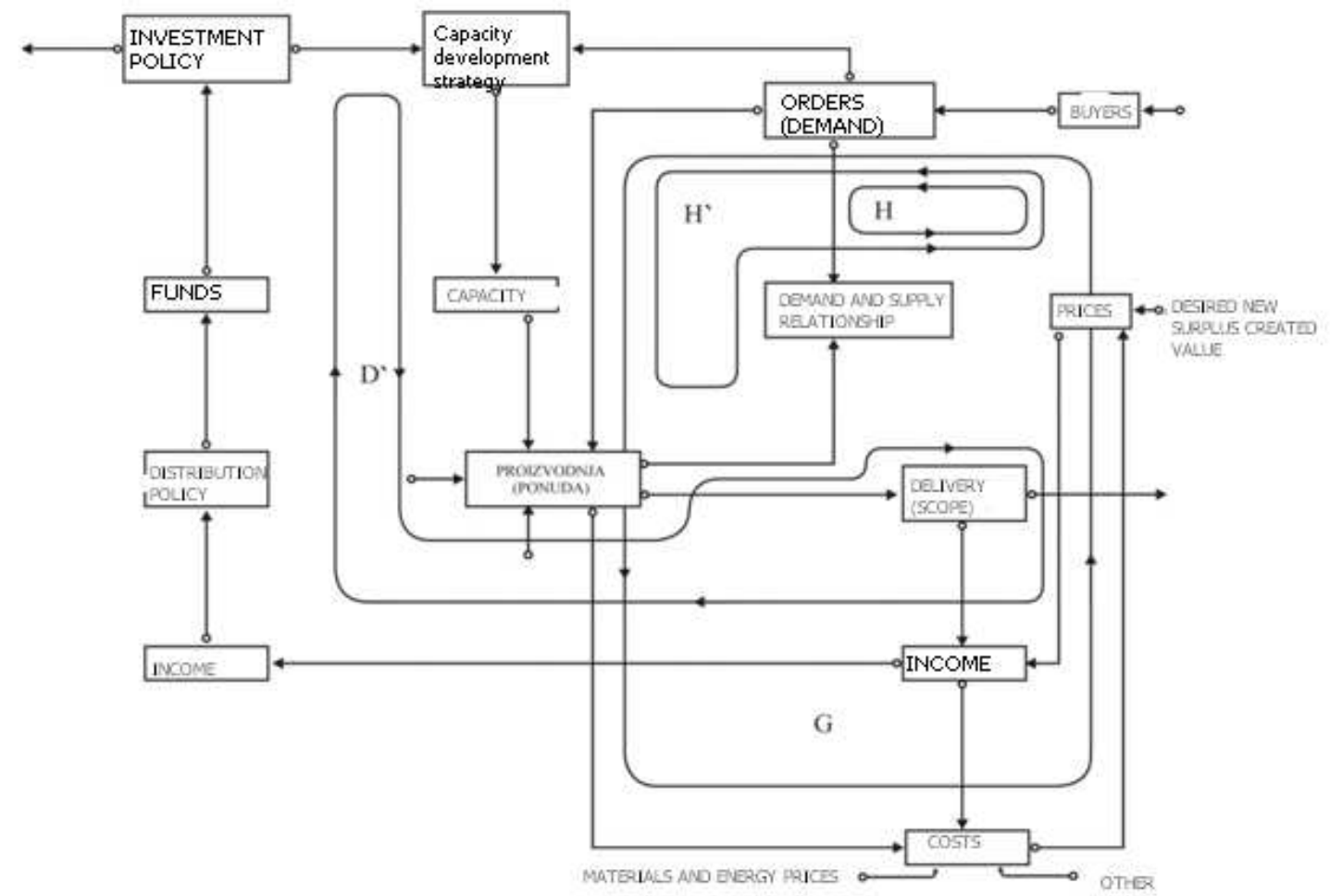

Figure 2. Processes management - Business function 2.

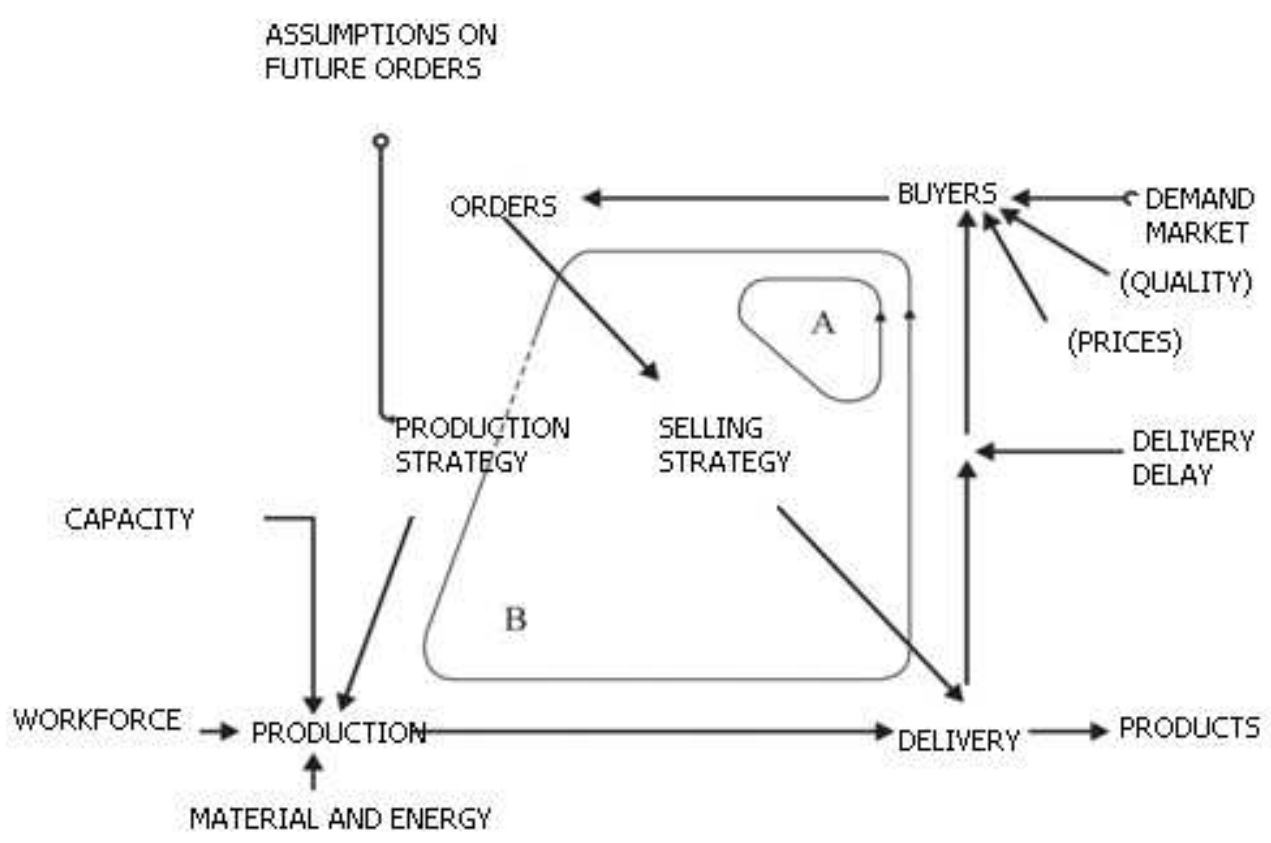

Figure 3. Processes management - Business function 3.

\subsection{Factors operations and growth of the enterprise}

On corporate performance affects factors of the economic development of the country, the trade balance of the country, the banking and credit system of the country's monetary, system and product-pricing policies, systems of instruments, and the investment and financing policies of the reproduction process in the company. 
Factors of economic development of the country today, finds its basis in the changes in the field of science and technology and human knowledge. Therefore, as key development factors of economic development are taken ${ }^{2}$ :

- population,

- natural and energy resources,

- technological change,

- fixed assets and infrastructure,

- organization and entrepreneurship and

- the organization and knowledge.

Production is not an goal for itself - it is qualitatively and quantitatively adjust the needs of society for their satisfaction. In the market, the needs are manifested in the form of demand, while the production supply mirror. For these reasons, each firm must understand its place in the overall supply and demand of its products in the relevant market in the coming period, as this is the basis of enterprise planning, growth and development, as well as conducting business policy.

Product, as a result of production, is interesting from the standpoint of its demand forecasts and future investments. With the new demand is important to determine the degree of saturation of the market specific products that are changing with time. Saturation is estimated by the ratio of the current number of customers in relation to the maximum possible number of customers. What is the ratio closer to 100 percent, the possibility of new demand is lower.

Demand for replacement products is inversely viewed in relation to the new demand. It was the first higher in nondurable products and therefore speaks of the high frequency of demand per unit of time. Formation of purchasing power in different subjects demand a different and related to the different time periods.

Factors influencing the demand for certain products are different. For non-durable consumer

\footnotetext{
2 S. Stefanović, R. Cvejic, D. Kostic, FUNCTIONS THAT CAUSATIVE AFFECTS TO THE IMPLEMENTATION OF REENGINEERING FROM THE ASPECT OF GENERAL FINANCIAL PARAMETERS, Lucrarea trimisă redacției Metalurgia International a fost acceptată spre publicare în numărul din 2013., ISSN 1582 - 2214, "METALURGIA INTERNATIONAL" is introduced in THOMSON SCIENTIFIC MASTER JOURNAL LIST, letter M, position 440. vol. 18 SPECIAL ISSUE NO. 8, str. 240 246 (2013).
}

goods, to the population, the price of the product and the price of its substitutes and complements, the purchasing power of the population. For durable goods, other than those listed above should be added to the time of their use, as well as inventory levels of these products in the subjects demand. These products are for purchase, in addition to their own resources, can use borrowed funds also.

Market analysis should define needs, motivations and behaviors of customers. The product market is aimed at meeting the needs of buyers and sellers. On the potential market is manifested consumer interest in a defined range of manufacturers. Available on the market, consumers have access to a particular market offer. On the penetrated market, consumers buy the products of companies. Relevant market is of strategic importance for the company.

The internal factors operating companies include:

- capacity of the company,

- available workforce,

- available resources, and

- other resources companies.

Under the capacity of companies include in its technical ability to produce a certain quantity of products, processing of certain quantities of raw materials, the performance of certain amounts of valuable services and a certain amount of effective work hours worked by means of work (capacity). The established capacity of the company's is business policies limiting factor. The time required for the purchase of capacity is relatively longer than other elements of production, their reproduction coefficient is small and for their supply required significant financial resources. Capacity of work instrument expresses by the quantity of finished products which means it can produce in a given time. In some cases, funding capacity for work is expressed in the amount of processed raw materials. For some funds for capacity is expressed in the amount of useful actions that these funds could be done in a given time (eg. engine speed). With those funds for which have varied applications for the expression of the capacity is used effectively during labor resources for the work per unit time (eg. in machines for metalworking, woodworking, 
etc.). Temporal expression of capacity can be annual, monthly, weekly, daily and by one hour.

Under the available workforce means the current number of workers employed in certain kinds of degrees and qualifications. The labor force is more flexible factor of production in relation to the tools and materials, and therefore the need to constantly adjust the basic production plan and all other partial plans. Workforce planning problem should not exist in a market economy. It solves by the constant hiring and firing of labor, as the ideal form of adjustment of the production plan with a plan manpower needs. In the long planning period, which is the dominant enterprise development, the essential role of available skilled labor force that primarily provides keeping up with the scientific and technical progress.

Available resources in the enterprise can be traced in two ways: as the available natural resources and raw materials available. Available natural resources occurring in companies in the fields of agriculture, forestry, water management, mining and like and must be qualitatively and quantitatively monitored. The available resources of the company were purchased quantities and types that also have to follow in the short term.

In other company resources we can include working capital and other financial resources.

\subsection{Financial planning for the development of companies}

Financial planning addresses the provision of resources and their allocation on the basis of investment decisions, ie. the growth of the company. Raise funds to finance the production of the task manager, as well as determining the proper investment strategy. Management companies can choose the strategy of high investment levels, with the aim of increasing participation in the existing market, may choose the cost optimization while maintaining the same growth, or opt for minimal investment and with a limited number of activities.

Investments are typically made in the results of scientific research such as product, instruments of labor, materials, research and development, new technology, etc.
Cost planning must be carried out continuously, the places of origin and cost. If you plan on places of origin, then the cost-based plan for places may assess effective business organizational units in the company. Planning costs for carriers (products), through working capital turnover, influences the commitment of these funds, which means the reduction of the many costs associated with working capital.

Pricing of the product cost determines the lower limit, and the effect on higher or lower income tax. The price of the product will also affect the capacity of the company, supply and demand in the product market, product characteristics, government intervention, monetary factor. The plan is an expression of the total revenue of the entire business enterprise in the future. It is based on all the partial policies for companies that planned period and stems from the realization of the planned price of products and services. Financial calculation includes the operating and financial income, non-operating and extraordinary income and revaluation income. The financial result can be positive or negative, depending on whether the income is higher or lower than the expenditures in fiscal year.

\section{MARKETING FUNCTION $\left(R_{M}\right)$}

Small or medium sized enterprise must always be facing buyers of their products and to their users. This strategy integrates all the business functions of the company and guide them to achieve defined business activities. Modern marketing should be viewed as a process of ensuring an optimal level of customer satisfaction with the achievement of optimal profit for the company as well as achieving optimal financial and work satisfaction for all employees in a small or medium size company.

The structure of the marketing function in a small or medium enterprise is caused by internal factors (activity of enterprises, business program, way of selling products) and extreme factors (market, current conditions, etc.). For these reasons, the marketing function involves basically three types of tasks related to the operation of the company as follows ${ }^{3}$ : 3 S. Stefanović, R. Cvejic, D. Kostic, FUNCTIONS THAT
CAUSATIVE AFFECTS TO THE IMPLEMENTATION OF
REENGINEERING FROM THE ASPECT OF GENERAL 
1. marketing strategy that analyzes and determines the strategy of small and medium enterprises,

2. market (performs the following functions within the production: research and processes the market, carries out the promotion and advertising of products and companies, conducts public relations),

3. commercial jobs: perform new contracts and the sale of products.

\section{FUNCTION OF SCIENTIFIC RESEARCH $\left(R_{N R}\right)$}

Scientific research has as a result new and improved products, more efficient tools and technological processes, better materials, energy resources and organizational methods. The study begins with basic research, and ends with a new or improved product and process design and material. Applied research means research that has resulted in the acquisition of knowledge that can be used for enhanced or new products, production processes and raw materials. Developmental research is a continuation of applied research in developing new products, improving existing ones, as well as developing new and improving existing technological processes and resources.

Research products can go in the direction of innovation, ie. discovering new products (offensive research), or in improving existing products (defensive research). As a result of product innovations of their own research work or the result of other people's decisions (purchasing the license), it is needed for conditions such as personnel, equipment, funds and others. Therefore, the necessity arises as to create material and personnel prerequisites for securing permanent process of innovation on the basis of their own research work. Only in this way can enable the continued presence of technical progress, which provides acquisition or retention of benefits and the favorable development of this enterprise.

The task of the whole society is to undertake a series of measures and concrete actions to create the necessary conditions and social climate for the development of innovative activity in the economy. These measures would be implemented through a coordinated program of social action, a measure of the company, as well as measures in the field of education. A coordinated program of social action should enable the development of a mass technical creativity. Therefore, it is necessary to stimulate enterprise and innovation in the work of individuals, through various incentives and exemptions for various expenses. Menagment job is to create a climate for innovation organized labor, which together with the detailed system of remuneration should form a whole.

Purchase of licenses is another way of winning new products and occurs when its own scientific research does not result in a new product. Using someone else's technology can only be successful if it fits into the existing economic structure of a country and, if applied. Each company, in order to further develop, has the right to buy and industrial property rights: patents, trademarks, patterns and models, so-called knowhow (knowledge). Purchasing a license is shortening the time winning products, personnel are trained by the vendor license, the product is in the process of prosperity, enabling faster start and continuity of production.

Each company needs to work on accelerated learning. Innovation program should include activities aimed at the formation of available personnel resources. Innovation program should allow for the creation of the strategy of technological development of the company, and within that patent and licensing policy.

The basic condition for economic development as a strategic enterprise and beyond, is the planning of scientific research, and thus product planning. Planning research and research products specifically requires defining its goals and tasks stemming from company goals. 


\section{FUNCTION OF THE MANAGEMENT ACCESS IN PRODUCTION PLANNING}

Production at the company is central question to competitive strategy of enterprise and innovation of production becomes a central policy issue in which the program and plan of production take central place. Connection marketing and production functions is viewed in several critical areas such as product programs, economies of scale of production, quality of products, economies of flexible manufacturing systems. The main promoter of change is the technology market. Market to competition, offers the advantage of industrial production, while technology gives the advantage of new technological processes and products.

In the area of production impacts by the introduction of so-called flexible manufacturing as a strategic task managers in the company, which the company is to provide a strategic advantage. Economy flexibility of production requires flexibility of functions: research and development, marketing and planning, materials and energy. Such a system of flexible production should enable many kinds of products with low production costs, regardless of the production volume is determined by market demand. The system should provide the offensive conquering the market with new products. These new products are those whose life cycle is extremely short. This shortening of the product life cycle, the company is constantly on the profit zone, avoiding competition and imitation of other manufacturers.

The choice of product depends on the size of the company and of its organizational form, which is determined by the characteristics of the work process. Production program will be rational if it is based on continuous improvement, change and modification of existing products, the elimination of obsolete and introduction of new products, which also talks about the dynamics of the production program. Optimal production program should enable the company maximum revenue with minimal spending, with clearly defined types of products and services based on customer requirements. Only conceived production program has a decisive role in the further growth and development. Product life cycle curve should show the duration of each product from the product range and the age of the entire product range.

Research work on changing production program should occupy an important place in business enterprise policy. Management in this regard must be given to risk research, funding, planning and organization of research work, the problem of personnel, costs of research and potential applications of the results obtained.

\section{FUNCTION OF FINANCIAL PLANNING IN GOAL OF ENTERPRISE DEVELOPMENT}

Financial planning addresses the provision of resources and their allocation on the basis of investment decisions, ie. the growth of the company. Raise funds to finance the production of the task manager, as well as determining the proper investment strategy. Management companies can choose the strategy of high investment levels, with the aim of increasing participation in the existing market, may choose the cost optimization while maintaining the same growth, or opt for minimal investment and with a limited number of activities.

Investments are typically made in the results of scientific research such as product, instruments of labor, materials, research and development, new technology, etc.

Investing in reengineering is not just selfexpansion of capital, it is also a process that consists of the following stages ${ }^{4}$ :

1. rate synergetic potential investors to invest in small and medium enterprises $\left(A_{1}=\left\{a_{11}, a_{12}, a_{13} \ldots.\right\}\right)$;

2. choosing targets small and medium business enterprises $\left(D_{1}=\left\{d_{11}, d_{12}, d_{13} \ldots\right\}\right)$;

3. choice of targets investments in small and medium enterprise $\left(A_{2}=\left\{a_{21}, a_{22}, a_{23} \ldots.\right\}\right)$;

\footnotetext{
4 S. Stefanović, R. Cvejic, D. Kostic, FUNCTIONS THAT CAUSATIVE AFFECTS TO THE IMPLEMENTATION OF REENGINEERING FROM THE ASPECT OF GENERAL FINANCIAL PARAMETERS, Lucrarea trimisă redacției Metalurgia International a fost acceptată spre publicare în numărul din 2013., ISSN 1582 - 2214, "METALURGIA INTERNATIONAL" is introduced in THOMSON SCIENTIFIC MASTER JOURNAL LIST, letter M, position 440. vol. 18 SPECIAL ISSUE NO. 8, str. 240 246 (2013).
} 
4. analysis of the domestic and global markets products $\left(A_{3}=\left\{a_{31}, a_{32}, a_{33} \ldots.\right\}\right)$;

5. preliminary selection of the production of small or medium of enterprises $\left(U_{1}=\left\{u_{11}, u_{12}, u_{13} \ldots\right\}\right)$;

6. technical - technological analysis equipment small and medium enterprises $\left(A_{4}=\left\{a_{41}, a_{42}, a_{43} \ldots\right\}\right)$;
7. choosing technology strategies of companies $\left(D_{2}=\left\{d_{21}, d_{22}, d_{23} \ldots.\right\}\right)$;

8. Investment analysis $\left(A_{5}=\left\{a_{51}, a_{52}, a_{53} \ldots\right\}\right)$;

9. cost analysis $\left(A_{6}=\left\{a_{61}, a_{62}, a_{63} \ldots.\right\}\right)$;

10. analysis of the expected effects of production and marketing $\left(A_{7}=\left\{a_{71}, a_{72}, a_{73} \ldots.\right\}\right)$.

The way of their relationship is shown in the following figure 4 .

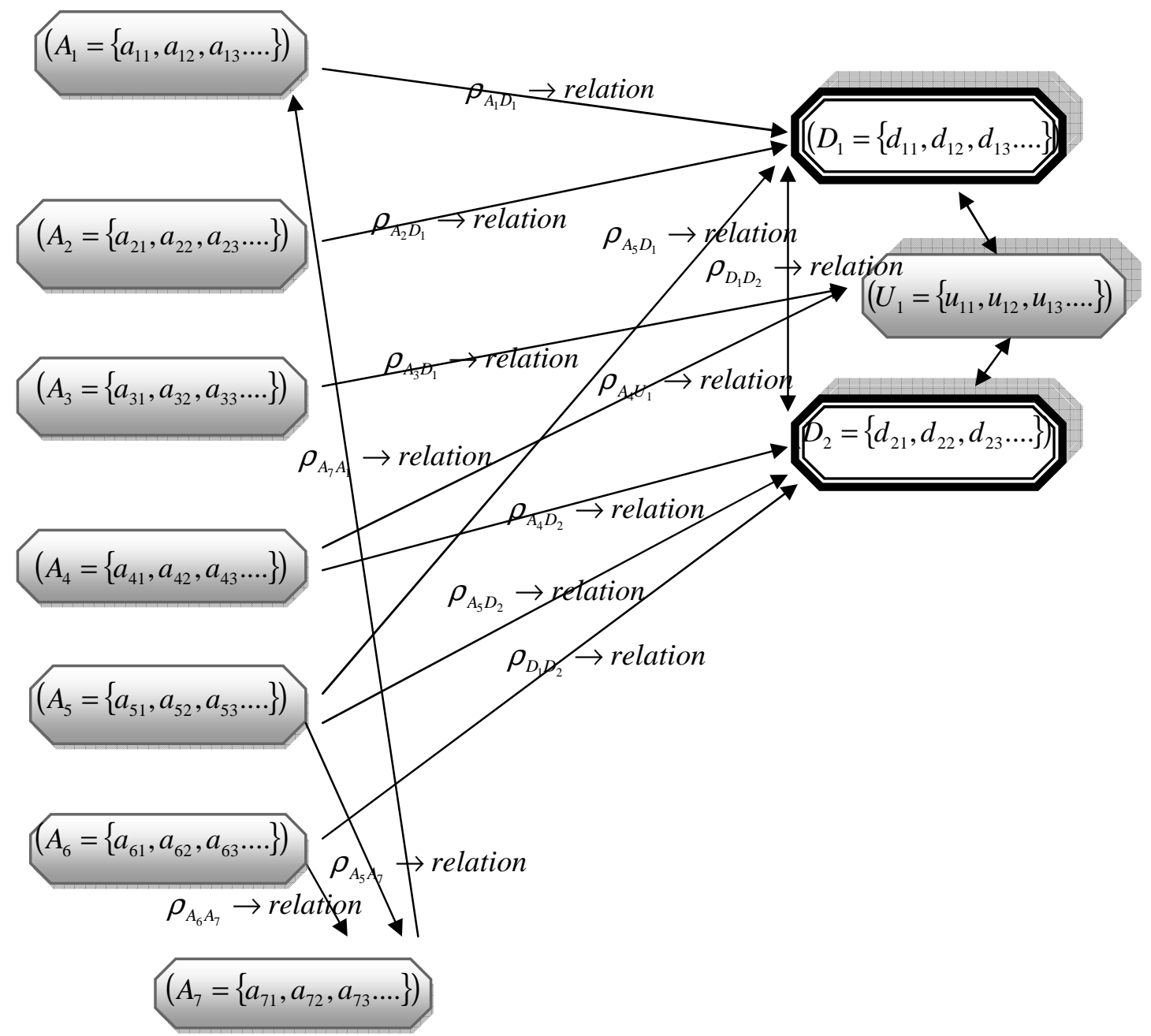

Figure 4. Connectivity graph of investment as a function of reengineering ${ }^{5}$

\footnotetext{
${ }^{5}$ S. Stefanović, R. Cvejic, D. Kostic, FUNCTIONS THAT CAUSATIVE AFFECTS TO THE IMPLEMENTATION OF REENGINEERING FROM THE ASPECT OF GENERAL FINANCIAL PARAMETERS, Lucrarea trimisă redacției Metalurgia International a fost acceptată spre publicare în numărul din 2013., ISSN 1582 - 2214, "METALURGIA INTERNATIONAL" is introduced in THOMSON SCIENTIFIC MASTER JOURNAL LIST, letter M, position 440. vol. 18 SPECIAL ISSUE NO. 8, str. 240 - 246 (2013). 
Cost planning must be carried out continuously, by the places of origin and cost. If you plan on places of origin, then the costbased plan for places may assess effective business organizational units in the company. Planning costs for carriers (products), through working capital turnover, influences the commitment of these funds, which means the reduction of the many costs associated with working capital.

Pricing of the product cost determines the lower limit, and the effect on higher or lower income tax. The price of the product will also affect the capacity of the company, supply and demand in the product market, product characteristics, government intervention, monetary factor. The plan is an expression of the total revenue of the entire business enterprise in the future. It is based on all the partial policies for companies that planned period and stems from the realization of the planned price of products and services. Financial calculation includes the operating and financial income, non-operating and extraordinary income and revaluation income. The financial result can be positive or negative, depending on whether the income is higher or lower than the expenditures in fiscal year.

\section{THE FUNCTION OF PLANNING AND CONTROL OF BUSINESS $\left(R_{P K P}\right)$}

This function can be parsed into the following sub-functions as follows:

1. planning that includes: strategic, medium-term, annual, operational, project;

2. predict the conditions and measures for the implementation of business plans;

3. control monitoring and analyzing the execution of business plans.

\section{ECONOMIC - FINANCIAL FUNCTION $\left(R_{E F F}\right)$}

Economic - financial functions in a small or medium size company includes all operations that result from the development and management of cash flow and capital.
The role of this function is reflected in securing and maintaining financial balance for the unimpeded flow of business financial realization of company goals.

This function consists of the following segments:

1. financial package tour (planning, acquisition and use of capital);

2. accounting (accounting and operations);

3. commercial transactions;

4. audit - oditing (internal or external audit).

\section{FUNCTION SETTING SALARIES FOR PERFORMANCE $\left(R_{V Z P}\right)$}

Establishing a direct link between actual earnings and performance usually is accomplished in the following ways, through:

1. pay rise,

2. stimulation, and

3. risk salary.

These methods vary in terms of guaranteed earnings, the relationship between the base salary and the arket share of wages relative to the total economic performance and so on.

Structure of total earnings by linking wages to pervormanse in terms of reengineering based on the market-determined wages to profits and less risk include:

a) total salary $=$ basic salary + pay rise

b) total salary = basic salary + stimulation.

Raises (Merit) is part of the earnings of which are in the size in money determined based on individual performance. This method is characteristic of earnings provided from the employer on the basis of the following characteristics: focus is directed at the individual performances of employee performance are subject to subjective value, given a raise once an integral part of the employee's salary regardless of future pervormansi. This last characteristic has a direct impact on the re-engineering in the 
sense that the employer assumes the risk of a continual increase in the wage bill.

Incentives have become very topical in recent times because of increasing disparities between the major managerial and other earnings. The assumption is that the traditional approach of creating the reward system provides a weak link between performance and reward, and a desire that all employees participate in organizational prosperity of small and medium enterprises. The difference is that the incentives provided by precisely defined period of time and do not become part of the employee's salary. This method of compensation is not solely related to individual performance, but there are stimulaije related to group performance.

Risky salary (Earnings at Risk) are salary whose employees themselves take the risk of their size. Usually they are used for staff involved in selling the products of small and medium enterprises as well as the manager.

\section{ANALYSIS OF THE PARAMETERS OF COSTS ARISING BY THE IMPLEMENTATION OF PROCESS REENGINEERING}

In addition to the basic cost of reengineering applications in small and mediumsized enterprises, it is necessary to analyze the parameters and costs resulting from the implementation of the business process reengineering activities and personnel revitalization ie. adjustment of organizational structure in terms of ownership restructuring, which includes four main groups of economic parameters ${ }^{6}$ :

1) Economic parameters of financial rehabilitation of a small or mediumsized enterprises $N E E_{F S}$, by introduction of re-engineering which includes the introduction of integrated

\footnotetext{
6 V. Vucic, S. Stefanović, HOLDERS OF ECONOMIC IMPACTS OF REENGINEERING PROCESS IN SMALL AND MEDIUM ENTERPRISES, Lucrarea trimisă redacției Metalurgia International a fost acceptată spre publicare în numărul 2013., ISSN 1582 - 2214, "METALURGIA INTERNATIONAL" is introduced in THOMSON SCIENTIFIC MASTER JOURNAL LIST, letter M, position 440.
}

logical system in a small or medium size company.

2) Economic parameters that ensure the functioning of the enterprise for the implementation of reengineering.

3) Economic parameters that ensure the functioning of all the processes and structure of quality systems in small and medium-sized enterprises by implementing the reengineering $N E E_{S K}$.

4) Economic parameters that ensure competitiveness in price of the product on market $N E E_{C P}$ resulting in a production environment using reengineering.

\section{Economic parameters of financial rehabilitation of a small or medium-sized enterprises $N E E_{F S}$, by the introduction of re-engineering which includes the introduction of integrated logical system in a small or medium size company}

The process of procurement, manufacturing and physical distribution are essential elements of integrated logical system of a small or medium enterprise. Logical integrated system includes a logical domain in which exhibit activity and impacts of integrated system that is logical ie. abutment totality of logical functions.

The logical system of a small or medium enterprise reengineering techniques can be applied to the whole logic of the system or some of its selected processes.

Reengineering logical system of small or medium-sized enterprises is based on the analysis of the system that encourages interaction in the structure and logic of the system of internal and external integration processes.

The initial framework for the
implementation of logical systems
reengineering procedures are:


PHASE I: Determine the initial values of the logical performance $N E E_{\text {FS IFAZA , }}$

PHASE II: Measuring the performance of logical systems $N E E_{\text {FS IIFAZA }}$.

The first stage involves determining the initial value of logistics performance. It analyzes the results in relation to the value within a small or medium enterprise (internal analysis) and by re-engineering compares them with the results of competitive successful companies. The first involves the use of a form of logical data obtained from the activities and publications of researchers and consultants (these are costs that occur at their engagement). The second form includes companies belonging to associations and organizations (costs incurred paying membership in these organizations) which mediate between cooperative members in the exchange of data to be used for the purpose of re-engineering. The third involves initiative of enterprise that to the necessary data come in contact with companies that are not in directly competitive relationships (costs of arrivals, departures and receiving delegations of enterprises).

The second phase involves the performance of enterprise logistics system, which includes a robust picture quality logistics systems companies:

1) Inventory management strategy,

2) Speed of response to customer needs,

3) Number of adverse events.

Stock level indicates the efficiency of the logistics system and its ability to respond to the needs at a cost that should weigh a minimum (which cause unnecessary costs of inventories of spare parts, materials, semifinished products).

Speed of service response indicates an intention and ability of small and medium enterprises to meet the demands of the market (decrease in profit due to untimely production ie. placing sufficient quantities of products on the market).

Number of adverse events in a logical system (technical system failures, poor product quality, damage to the goods - products during handling and transport activities unnecessarily repetitive) cause additional costs and also based on them are made mark quality management policies, ie. evaluating the overall opinions about the logical support.

Directly monitoring the effectiveness of logical systems before, during and after implementation of design solutions reengineering is done by the system for the continuous measurement and monitoring of logistics performance. On the basis of it can be traced:

1) Delivery time on demand (less time results less cost),

2) The delivery time for the product (less time results less cost),

3) Delivery time per customer (less time results less cost),

4) Time to registration order (less time results faster preparation times and smaller cost),

5) Mean time between failures in the operation of the technical system (long time results by productivity is increased and costs are reduced),

6) All other company costs (these will be discussed in the next section).

\section{Economic parameters that ensure the functioning of the enterprise for the implementation of re- engineering $N E E_{K P}$}

To provide entrepreneurship it is necessary that there are responsible carriers or entities that move, realize in implementing the results of reengineering. By M. Hammer and J. Champy among the main protagonists of the process reengineering: Supervisory Board (Steerring Comittee), Reengineering Team and processes leader. For W. Bennis and $\mathrm{M}$. Mischea key carriers of reengineering are executive sponsors, board of directors, a transformational leader, process protector and re-engineering team. D.K. Carr and H. J. Johansson among the major participants in the process of reengineering include: Board of Directors (Executive Council), work ie. process re-engineering teams, line management and support staff - counselors. 
Although there are some disparities in the division, they can find an appropriate match. From these coincidences occur basic groups of holders of process reengineering, as follows:

1. Board of directors or executive council (Steerring Comittee) or the Board of Directors,

2. Reengineering team (work ie. process re-engineering teams),

3. Process Leader (transformational leader).

Economic parameters that ensure the functioning of the enterprise for the implementation of reengineering affect the amount of income of small and medium enterprises in terms of providing basic salary carrier group process reengineering.

\section{Economic parameters that ensure the processes functioning of all structure and the quality systems in small and medium- sized enterprises by reengineering $N E E_{S K}$}

Each team leader for the implementation of re-engineering in small and medium sized companies must actively participate in the management process reengineering which are: the quality system in company, production system, system maintenance, system of organization and management, and others. In order to have success it is necessary to constantly monitor and improve the quality system of the company which includes a number of subsystems that have their own economic parameters and actively participate in the formation of prices of products including ${ }^{7}$ :

7 V. Vucic, S. Stefanović, HOLDERS OF ECONOMIC IMPACTS OF REENGINEERING PROCESS IN SMALL AND MEDIUM ENTERPRISES, Lucrarea trimisă redacției Metalurgia International a fost acceptată spre publicare în numărul 2013., ISSN 1582 - 2214, "METALURGIA INTERNATIONAL" is introduced in THOMSON SCIENTIFIC MASTER JOURNAL LIST, letter M, position 440.
1) Economic parameters resulting from the formation of the internal metrology with a network of accredited laboratories $N E E_{I M}$,

2) Economic parameters due to the formation of internal standardization $N E E_{I S}$,

3) Economic parameters resulting from the formation of the system reliability of the technical systems and power plants and infrastructure (technology introduction costs) $N E E_{T O}$,

4) Economic parameters resulting from the formation of the system design $N E E_{D}$,

5) Economic parameters of the system due to the formation of deposit, destruction and recycling received bad products $N E E_{D U R}$,

6) Economic parameters resulting from the formation of the system of quality after sales support $N E E_{P P P}$,

7) Economic parameters of the system due to the formation of product distribution $N E E_{D I}$.

From the above overall economic parameter that provides a process structure and functioning of the quality system in small and medium enterprises in the conduct of reengineering can be expressed:

$$
\begin{gathered}
N E E_{S K}=N E E_{I M}+N E E_{I S}+N E E_{T O}+N E E_{D}+ \\
+N E E_{D U R}+N E E_{P P P}+N E E_{D I} \cdot \quad \text { [2] }
\end{gathered}
$$

\section{CONCLUSION}

Dependence of re-engineering and its impact on the organizational structure of small and medium sized enterprices in condition of transition in this paper work is done through an analysis that included basic business functions in a small or medium size company, which is explained by an important segment of the business. 
From the preceding it can be said that reengineering is a radical approach to restructuring and redesigning of all business activities of the company in goal to innovate operating activities and to increase profit of the company in relation to the aim of improving the competitiveness of implementing asked organization structure which achieves the improvement of the quality of the business. In the most general sense of re-engineering is a new beginning ie. it is a rejection of conventional understandings and assumptions about the structure of the past and the company represents a new approach to process finding a structure that very little or reminiscent of the one from the past. Therefore, as a method reengineering is essential for the organization and implementation of the smaller companies primarily because of its competitiveness in the market. In this type of change in business processes, instead of each stage, or even individual operations in the business process, assign an employee, every employee here is debited for a client of that process, performing all operations that need to be done, in order to meet needs of the client. In doing so, the customer can be internal or external. In fact, it may be a buyer of products or services, but also employees, or organizational unit in an enterprise that uses the results of the previous phase of work, and with the use of economic effects.

\section{REFERENCES}

1. Abrahamson, E., Change without pain, Harvard Business Review, July-August, 2000.

2. Adamović Z., Stefanovic S., Mrdak G., Pajic S., Business process reengineering IN SMALL AND MEDIUM ENTERPRISES, scientific - technical conference "Proactive maintenance machine", 15 - 16 May 2008. Vrnjačka Spa, (Proceedings on CD - in).

3. Adamović Z., Stojićević D., Reengineering, TF IMP, Zrenjanin, 2004.

4. Cameron, K.S. Freeman S.J., Mishra A.K., Downsizing and Redesigning Organizations, edited by George P. Huber and William $\mathrm{H}$.
Glick, Organizational Change and Redesign: Ideas and Insight forImproving Performance, Oxford University Press, 1995.

5. Cingula M., Fabac R. , POSLOVNI SUSTAVI I POSLOVNI PROCESI- MODELIRANJE I REINŽINJERING, Osijek, 2004.

6. Ford C. Robert, W. Alan Randolph, Organizational structure and project management, u knjizi Project Management Handbook, Project management Institute, edited by Jeffrey K. Pinto, Jossey-Bass Publishers, 1998.

7. Gavrilov O., Stefanovic S., Development of Information Society in Serbia as a precondition for the implementation of reengineering, scientific - technical conference "Proactive maintenance machine", 15 - 16 May 2008. Vrnjačka Spa, (Proceedings on CD - in).

8. Gouillart, F.J.,Kelly, J.N.,Transforming the Organization, McGraw-Hill, Inc, 1995.

9. Hammer,M., Rreengineering, Harvard Business Review, No5, 1990.

10. Zdravkovic D., Introduction to Economics, Five \& Co. Nis, 2007.

11. S. Stefanovic, General financial functions parmetri small and medium enterprises that causally affect the implementation of reengineering in transition, Scientific - sručni magazine "reengineering" no. 3 - 4, 2008th, p. 89-93, Zrenjanin, ISSN 1820-7294 UDC 005.

12. Stefanovic S., The economic effects of reengineering in SMEs, Ph.D., Megatrend University, Belgrade, 2010.

13. S. Stefanović, R. Cvejic, D. Kostic, FUNCTIONS THAT CAUSATIVE AFFECTS TO THE IMPLEMENTATION OF REENGINEERING FROM THE ASPECT OF GENERAL FINANCIAL PARAMETERS, Lucrarea trimisă redacției Metalurgia International a fost acceptată spre publicare în numărul din 2013., ISSN 1582 - 2214, "METALURGIA INTERNATIONAL" is introduced in THOMSON SCIENTIFIC MASTER JOURNAL LIST, letter M, position 440. vol. 18 SPECIAL ISSUE NO. 8, str. 240 -246 (2013).

14. S. Stefanovic, R. Cvejic, V. Vucic FORMATION OF ALGORITHMS REENGINEERING THROUGH THE BLOCK DIAGRAMS IN THE TRANSITIONAL ECONOMY CONDITIONS WITH FOCUS ON MANAGEMENT IN SMALL AND MEDIUM ENTERPRISES, Metalurgia International, Romania, 2013. 